\title{
Baltic Economies and Financial Crisis in the EU
}

\author{
Eva Banincova
}

\section{I . Introduction}

The Baltic States (Estonia, Latvia and Lithuania) recorded exceptionally high economic growth from 2001 to 2006 (with average real GDP growth rate exceeding not only the average of EU-15, but also that of the 4 new EU member states of Central and Eastern Europe (CEE)). However, since 2007 the economic downturn in the 3 Baltic countries became much more pronounced than in $\mathrm{CEE}$ and for 2009 all these 3 economies are forecasted to contract by more than 10\% (Figure 1).

This paper aims to specify those features of the Baltic economies that explain why they were the countries worst affected by the 2008-09 financial crisis in the EU. Therefore we first examine the characteristics of Baltic economic growth prior to 2007 (referring to the Baltics as one region, but when necessary pointing out some important differences among these 3 economies). Then we explain the onset of the recession in the Baltics. Next we outline several aspects of the crisis in the Baltics and examine policy responses to the crisis. Finally, we discuss a sustainable economic growth pattern for small and open EU economies. 
Figure 1 Real GDP growth rate (as \% change on previous year)

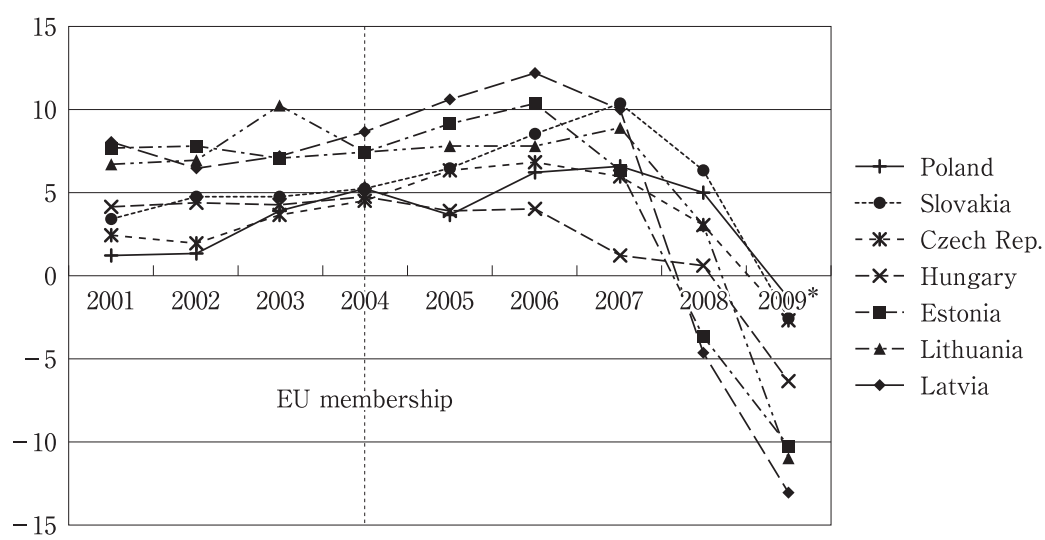

Source) Eurostat.

* GDP growth rate for 2009 is a forecast.

\section{Pre-crisis Baltic economies}

Due to their exceptionally high economic growth between 2000 and 2006, Baltic economies converged rapidly to the average EU GDP per capita. A significant difference in GDP growth of the Baltics and CEE is that GDP growth in the Baltics was driven mostly by domestic demand that expanded more dynamically than that in CEE.

Such strong domestic demand in the Baltics was supported by a very rapid expansion of bank credit to the private sector that demonstrated itself in expanding imports, which aggravated large current account deficits.

In 2001 the ratio of private sector credit-to-GDP in the Baltics was below the CEE levels; however, in 2005 this ratio was already higher in the Baltics than in CEE (except for Hungary). Credit growth expanded most dynamically in Lithuania and Latvia, followed by Estonia, while in Hungary it slowed down after 2003 and in 3 CEE countries credit growth 
Figure 2 Structure of Bank Loans to the Private Sector (as \% of GDP)

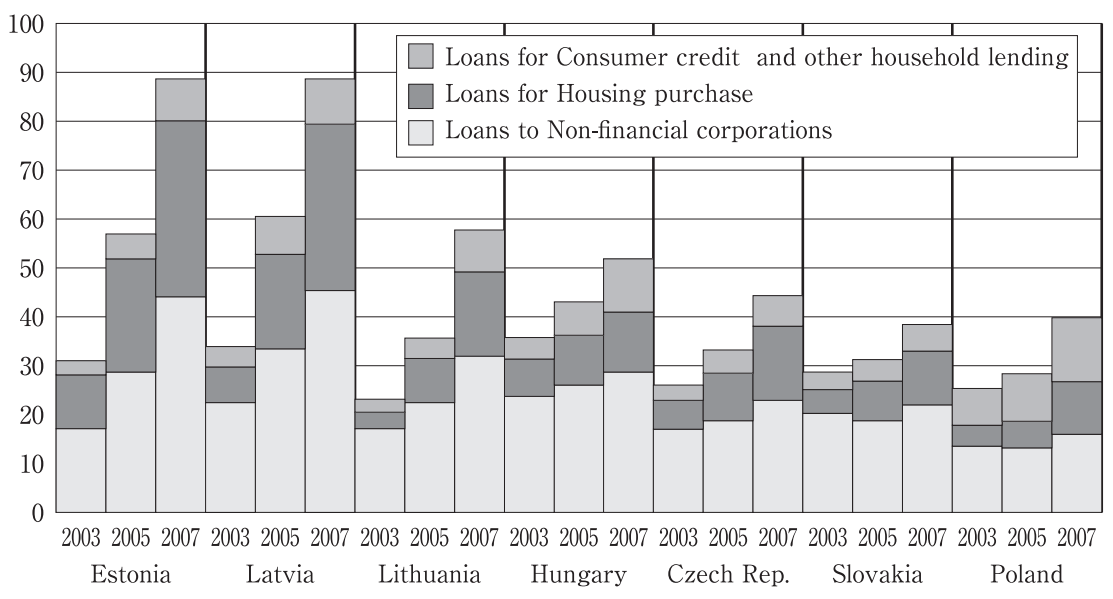

Source) ECB, EU Banking Structures, Years 2005 and 2008.

* Data of Loans for consumer credit and other household lending in 2003 for Lithuania and Slovakia was not available; therefore data for 2004 was used.

5)

was not dynamic.

There are two distinctive features in the structure of bank lending to the private sector in the Baltics. First, loans to households for housing purchases expanded rapidly in Estonia and Latvia, followed by Lithuania (Figure 2). Since in Lithuania corporate loans expanded more rapidly than the household loans, its lending structure slightly differed from the other 2 Baltic countries and resembled that of Hungary. The other $3 \mathrm{CEE}$ countries recorded much smaller expansion of three kinds of bank loans.

Second, in the Baltics a much larger share of loans (especially home loans) were denominated in foreign currency than in CEE between 2003 and 2007.

Now we will examine the connection between developments in the balance of payments and Baltic economic growth as characterized by credit expansion.

In 2002-06, similar to CEE, the combined surplus of the capital and 
Figure 3 Structure of Foreign Capital Inflows in Baltic States (minus indicates outflows)
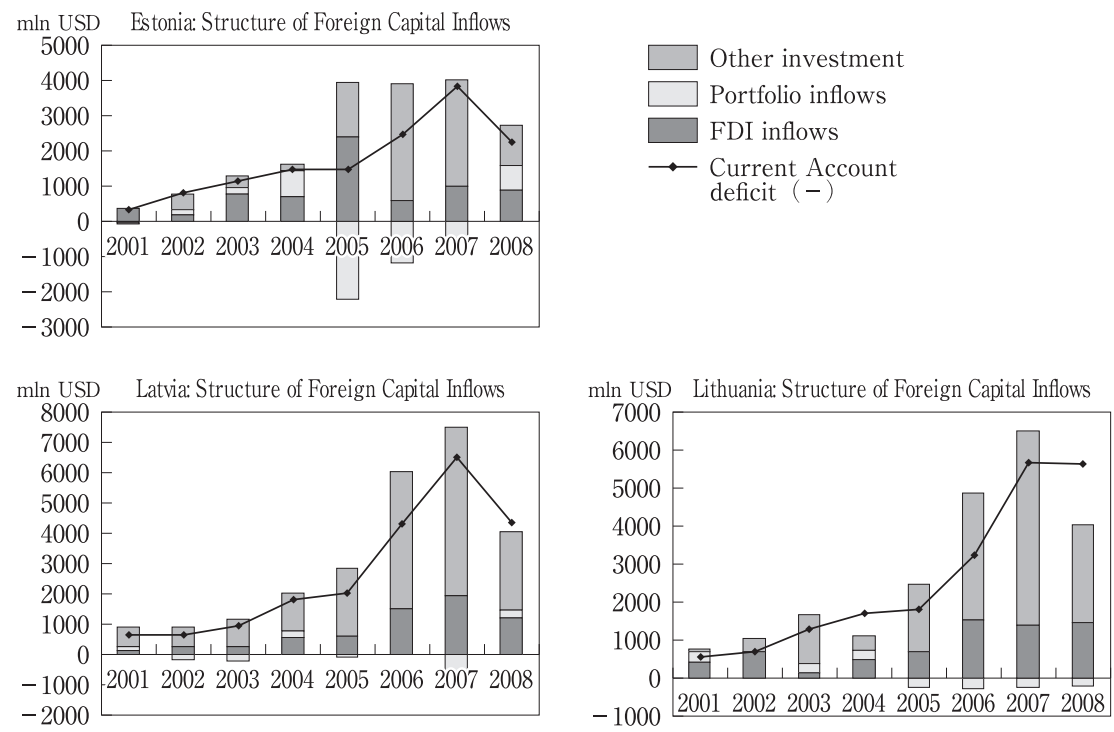

Source) IMF, International Financial Statistics and National Central Banks.

financial accounts exceeded the current account deficit, which means that reserves increased. After 2005, all three Baltic States experienced sharp increases in their current account deficits, but there is no evidence to suggest the same increase in CEE. However after 2007, the current account deficits in the Baltic States declined, while all CEE countries experienced increases in their deficits. Both CEE and Baltic economies depend on foreign capital to finance their current account deficits, but these deficits were considerably larger in the Baltics than in CEE and the structure of foreign capital inflows differed, as follows.

First, other investments dominated Baltic foreign capital inflows and clearly exceeded FDI (Foreign Direct Investment) after 2005 (Figure 3), while FDI inflows tended to dominate capital inflows in CEE.

The area labeled 'other investment' consists mainly of intra-group bank 
loans, and as developments in bank balance sheets in Figure 4 illustrate, due to having such a large capital supply from foreign (mostly Scandinavian) parent banks on the liabilities side, Baltic subsidiaries were able to expand their lending much more than if they had relied only on the traditional deposit base. This was demonstrated by high loan to deposit ratios in the Baltics (and Hungary), compared to the $3 \mathrm{CEE}$ countries.

Second, there is a difference in the distribution of FDI inflows across economic sectors. FDI in Estonia and Latvia instead of being absorbed by manufacturing (only 15\% of total FDI on average for 2001-08 went into manufacturing) was mostly concentrated in financial and real estate sectors. As a result, we have already seen that household loans expanded in these 2 countries more rapidly and on a much larger scale than in Lithuania and CEE. On the contrary, in CEE a relevant share (around $30 \%$ ) of FDI was occupied by manufacturing. Interestingly, Lithuania is in this respect similar to CEE, since FDI in manufacturing represented 28\% of total FDI and this can explain why corporate loans had a significant share in the total bank loans.

In addition to macroeconomic developments in the balance of payment, credit growth in the Baltics also needs to be explained by the combination of several factors on the demand-side and supply-side of credit (Figure 4). Some factors (such as the so-called catch-up effect that was further strengthened by a smooth EU accession process or the creation of foreign-bank dominated bank system) were observed in both Baltics and CEE, but the following specific factors on the demand-side of credit developed only in the Baltics.

There has clearly been a pent-up demand for housing. Owner occupation rates of houses in the Baltics have been high and the housing demand was further reinforced by rapidly increasing personal incomes since 2000. Housing demand continued to exceed the housing supply, as the construction of new houses sped up only after 2004. This was mainly owing to the EU accession (adoption of the Acquis Communautaire 
Baltic Economies and Financial Crisis in the EU (Banincova)

Figure 4 Causes of Credit Growth and Onset of Recession (in 2007) in the Baltics

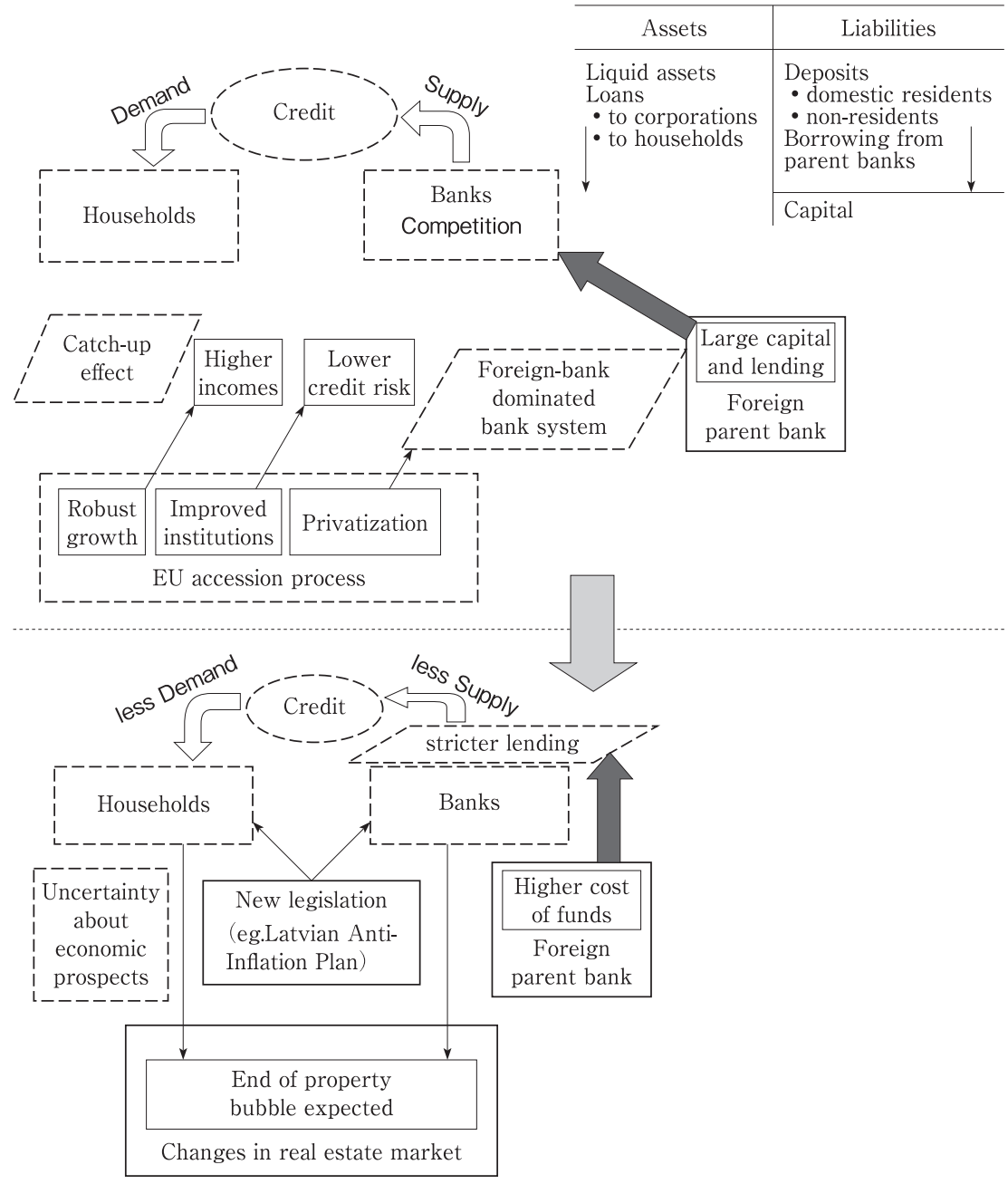


enabled smoother property transactions) and FDI into real estate activities, which largely increased after 2004.

Robust housing demand led to a rapid growth in housing prices, which became remarkable mainly after 2005 . As the gap between house prices and personal incomes widened, demand for housing loans was reinforced. Some special incentives such as housing loan guarantees also supported the increasing demand for housing loans. Escalating residential prices between 2004 and 2006 indicate real estate market bubbles were forming in Baltic countries. Speculative real estate investment as well as participation of foreign investors (to a certain extent) was also observed.

Baltic States and Hungary had a high share of foreign currency loans. In Hungary the interest rate differential between Euro and domestic currency played a predominant role as a motivating factor for foreign currency loans. Hungary's interest rate differential (calculated from the monthly average of the difference between domestic 3-month interbank rate and the 3-month EURIBOR) was $6.15 \%$ in 2003 and $9.42 \%$ in 2004 .

On the other hand, in the Baltic States the interest rate differential did not play such predominant role. All three Baltic States have operated fixed exchange rate regimes since the early 1990s and joined the ERM II with a restricted fluctuation band, therefore the exchange rate risk was perceived to be low by the borrowers. Moreover, Baltic States expected early transition to the Euro. Estonia and Lithuania operate currency boards, while Latvia has a fixed exchange rate regime with $\pm 1 \%$ fluctuation band continued as a unilateral commitment.

There has been a clear decrease in the interest rate differential between Estonia (and Lithuania) and the Euro area. Operating currency boards with the Euro as the base currency means that the inflation and interest rates of these two Baltic countries are relatively close to trends in the Euro. For Estonia, the interest rate differential was $0.59 \%$ in 2003 , but decreased to $0.39 \%$ in the following year and narrowed down to $0.1 \%$ in 2006. Interest rate differential for Lithuania was $0.5 \%$ in 2003 , 
but decreased to $0.24 \%$ in 2005 and became as low as $0.03 \%$ in 2006 . According to the Bank of Lithuania, this large decrease in interest differential between 2005 and 2006 was partially due to the expected Euro adoption in 2007 .

The above-mentioned difference of Latvia's exchange rate regime is reflected in the fact that Latvia's interest rate differential has always been higher than in Estonia and Lithuania and did not follow the same trend displayed by the other two Baltic States. Latvia's differential increased from $1.5 \%$ in 2003 to $2.1 \%$ in 2004 , but then it decreased to $0.89 \%$ in 2005.

The Bank of Estonia points out that foreign currency loans in Estonia have not been motivated by the interest rate differential, but rather follow the tradition of borrowing in the foreign currency that forms the foreign anchor currency of the Estonian currency board (in 1992 Kroon became pegged to German Mark, which was then replaced by Euro) ${ }^{21}$.

\section{Onset of Crisis in the Baltics}

The Baltic economic growth prior to 2007 consisted of the aforementioned features, which distinguished these 3 states from the CEE countries (Hungary being a partial exception), specifically through rapid credit booms (with a large share of foreign currency denominated household loans) funded by borrowing from foreign parent banks that helped to create real estate market bubbles. Consequently, Baltic economies faced 3 major vulnerabilities. First, such large external imbalances (current account deficits) were not sustainable over the long-term. Second, Baltic over-dependence on foreign capital implied a liquidity risk. Third, realestate market related risks for banks and the private sector increased. In particular, the private sector in the Baltics became vulnerable since indebtedness recorded three to four fold increases between 2002 and 2008, and the currency mismatch will remain until the Euro is adopted. 
In 2007 the real estate market bubble in the Baltics eventually collapsed (Figure 4). The speed of the price decline and its timing varied slightly among Baltic States, however, the following were common factors that contributed to the end of the property bubble: unsustainable price developments brought about by speculative transactions, decreased afford$\underset{233}{\operatorname{ability}}$ of housing, excessive housing supply and restricted supply of credit.

Speculative real estate investment that contributed to housing price increases drove property prices to exorbitant levels (real estate market experts acknowledged that housing prices were unreasonably and unsustainably high) ${ }^{24)}$. Exorbitantly high prices (as indicated by an increasing gap between housing prices and income levels) started to reduce housing demand from potential buyers (as evidenced first in Estonia between at the end-of 2006 and first half of 2007), and real estate transactions started to decline.

Gradual tightening of lending standards by banks was a common factor in all three countries. Banks anticipated the end of the bubble after observing these housing market developments, and in particular Scandinavian banks had experiences with credit booms and subsequent crises in their own countries. The trend of more conservative lending policies was reinforced when the banks started to face higher funding costs, due to increasing instability of global financial markets since 2007. In terms of stricter lending, the Latvian Anti-inflation plan (effective since July 2007) is considered to have been successful in reducing speculative real estate investments by setting up new and more prudent regulations for both banks and real estate buyers.

The construction sector could not quickly adjust to decreased demand and the oversupply of newly built dwellings became evident. Facing financial difficulties, as the Baltic economic recession deepened in 2008-09, construction and real estate companies had to start selling their property at considerable discounts which strengthened the downward trend in 
housing prices

The initial cause of the Baltic recession thus came from internal factors that were reinforced by external factors (limited credit supply). The end of the property bubble as well as credit tightening thus took place before the BNP Paribas shock caused the financial crisis in the EU to develop. Swedish banks, the main lenders in the Baltics, rely on funding from wholesale markets rather than on deposits (due to a generally low deposit base) and thus faced liquidity constraints when funding costs increased after 2007, which further tightened the credit supply from Swedish banks in the Baltics.

Since 2007 a declining trend of residential property prices in Baltic capitals became evident, with the most pronounced declines in the Latvian and Estonian capitals. In addition, a declining trend in household borrowing became evident in all 3 Baltic States after the fist half of 2007. Between the first and third quarters of 2008, domestic demand in the Baltics contracted more than in CEE.

\section{Crisis in the Baltics: Several Aspects and Policy Responses}

\section{Several Aspects of Crisis in the Baltics}

By the end of 2008, it became evident that Latvia's economic recession was the most severe among the three Baltic States. This was due to the following factors. Latvia had the largest current account deficits (of over $-20 \%$ of GDP in 2006-07) and the highest inflation in the Baltics between 2003 and 2007, meaning that Latvia faced the worst prospects for Euro adoption. Compared to Lithuania and Estonia (whose foreign bank ownership in terms of assets was as high as 85\% and 99\% respectively in 2007), only $67 \%$ of Latvian total bank assets were foreignowned. The implied liquidity risk was actually demonstrated in the case of Latvia's second largest bank Parex.

Parex, a domestically owned bank with a high share of non-resident 
deposits, lent extensively to the real estate and construction sectors. Following the fall in Parex's securities portfolio value, market participants in the second half of 2008 became uncertain about the bank's ability to repay its syndicated loans (due in February and June 2009). Due to a run on deposits in October 2008, when mainly non-residents withdrew over one quarter of deposits, Parex faced serious liquidity constraints. However, as a domestic bank, Parex could not expect any capital support from a foreign parent bank. The government decided to take over Parex in November 2008, which was approved by the European Commission. Nationalization took place in December 2008 when the government acquired $85.15 \%$ of the bank's shares.

Nationalization of Parex further aggravated the Latvian economic situation. Large deposits were moved from other Latvian banks (and several domestically owned Lithuanian banks) to Estonian banks (which were perceived to be the safest due to their well-capitalized Scandinavian parent banks). In October 2008, The Bank of Latvia had to intervene heavily to defend the fixed exchange rate. As a result, by November the central bank's official reserves decreased by nearly one fifth, therefore to preserve the fixed exchange rate when facing severe liquidity constraints, Latvia applied for a 27-month IMF Stand-by Arrangement in December 2008 .

The IMF-led international financial assistance to Latvia included participation by the EU, four Nordic States, Estonia, the World Bank and EBRD each contributing to the financial package totaling 7.5 billion Euro to be released in 6 tranches (first and second tranches were released in December 2008 and August 2009). Latvia's progress in consolidating its budget, stabilizing its financial sector and structural reforms is regularly monitored before the country can obtain each tranche of funds. In order to avoid devaluation, the so-called 'internal devaluation' has to be carried out in Latvia, which means that domestic prices and wages must be adjusted downwards by fiscal and income policies. Such strict internal 
adjustments have proved socially unpopular in Latvia, as demonstrated by anti-government riots in Riga in January 2009.

The IMF supported Latvia in maintaining its current fixed exchange rate, since any devaluation of the Lat is estimated to be contagious for the other two Baltic fixed rates. Baltic countries have operated fixed exchange rate regimes since gaining their political independence in the 1990s, thus maintaining their currency pegs is important on socio-political grounds too. Central banks of all Baltic States declared their strong commitment to the current fixed exchange rate regimes and refused devaluation. Devaluation would be particularly damaging for Baltic households and major Swedish banks would incur significant losses.

Both Estonia and Lithuania maintain currency boards and the scale of reduction in their foreign currency reserves between September 2008 and September 2009 was much lower than in Latvia. Reserves backing the Lat have decreased in the first half of 2009, with speculations of possible devaluation being highest in June 2009, but since Latvia successfully obtained the second tranche of its international loan, speculations of possible devaluation subsided.

The case of Parex illustrated how banks that have no support from a foreign parent bank and that rely on other funding sources rather than traditional residents' deposits (Figure 4 shows the expansion of liabilities in the bank balance sheets by non-resident deposits) become vulnerable and following a run on a bank, nationalization is inevitable.

Another aspect related to Baltic economies and the financial crisis in the EU concerns the risk of financial contagion (i. e. when problems in one bank can lead to problems for the whole bank system). Is there a high risk of such financial contagion?

Three main Nordic countries (Sweden, Finland and Denmark) account for a majority of foreign bank claims in the Baltics and Sweden is the most important creditor country in the Baltics. This "common lender" situation implies that as much as Baltic countries are vulnerable to 
Swedish economic conditions, Sweden itself is sensitive to Baltic economic conditions, as evidenced by the fact that Baltic countries now account for a majority of Swedish bank losses (between the fourth quarter of 2008 and first quarter of 2009, Baltic countries accounted for 39\% of total Swedish banks' loan losses).

Swedbank and SEB, as the two banks most exposed to the area, face the highest risk of credit losses (In the fourth quarter of 2008, lending to the Baltics as percentage of total lending represented approximately $16 \%$ for Swedbank and SEB, compared to only 3.2\% for Nordea). Market shares of these two banks indicate that economic conditions in Estonia and Latvia will most affect Swedbank, (in March 2009, Swedbank occupied $45 \%$ of Estonian and 26\% of Latvian bank markets), while SEB is most sensitive to the conditions in Lithuania and Estonia (where it occupies $30 \%$ and $24 \%$ of the bank market, respectively).

When examining the latest development in Swedbank and SEB in terms of their financial results and their response to the negative economic situation in the Baltics, the following common points are observed.

First, the total credit losses of both banks increased considerably (for Swedbank the total credit losses between the third quarter of 2008 and the third quarter of 2009 increased seven times, from 812 million SEK to 6.1 billion SEK. Total net credit losses of SEB increased from 448 million SEK in the second quarter of 2008 to 3.6 billion SEK in the second quarter of 2009).

Second, examination of these banks' loan losses by geographical area reveals that the increase in credit losses mainly reflects significant credit losses in the Baltics, which reached 3.3 billion SEK for Swedbank in the third quarter of 2009. Net credit losses in the Baltics for SEB reached 2.6 billion SEK in the second quarter of 2009. This has been accompanied by a higher share of impaired loans. For example, for SEB the share of impaired loans in the Baltics (as gross \% of total lending) increased from $0.68 \%$ in the second quarter of 2008 to $5.08 \%$ in the second quarter of 
Baltic Economies and Financial Crisis in the EU (Banincova)

Table 1 Selected Bank Performance Indicators

\begin{tabular}{|c|c|c|c|c|c|c|c|c|c|}
\hline \multirow{2}{*}{ Bank } & \multicolumn{3}{|c|}{ Size of Assets (USD mln) } & \multicolumn{3}{|c|}{ Assets/Tier 1 Capital } & \multicolumn{3}{|c|}{$\operatorname{ROE}(\%)$} \\
\hline & 2003 & 2006 & 2007 & 2003 & 2006 & 2007 & 2003 & 2006 & 2007 \\
\hline Swedbank & 137,778 & 197,102 & 250,715 & 23.8 & 28.5 & 31.6 & 23.2 & 32.6 & 24.7 \\
\hline$\underset{\text { (Est) }}{\text { Hansabank }}{ }^{*}$ Group & 8,080 & 25,536 & - & 10.2 & 14 & - & 25.6 & 28.9 & - \\
\hline$\underset{\text { (Lat) }}{\text { Hansabanka Group }}$ & $3,787^{* *}$ & 7,171 & - & $14.0^{* *}$ & 14.8 & - & $33.9^{* *}$ & 34.7 & - \\
\hline SEB & 175,862 & 281,808 & 365,545 & 30 & 31.9 & 32.2 & 19.3 & 27.4 & 25.5 \\
\hline SEB Pank (Est) & 2,061 & 5,971 & 8,287 & 9.7 & 12.5 & 11.5 & 23.1 & 27.9 & 30.6 \\
\hline $\begin{array}{l}\text { SEB Unibanka } \\
\text { (Lat) }\end{array}$ & 1,616 & 5,175 & - & 10.6 & 20.5 & - & 20.4 & 42.7 & - \\
\hline$\underset{\text { (Lit) }}{\text { SEB Vilniaus }}$ & 3,105 & 8,045 & - & 13.6 & 17.7 & - & 23.7 & 30.7 & - \\
\hline
\end{tabular}

Source) The Banker, Top 1000 World Banks and Top 100 Central European Banks, various issues.

* Hansabank is a fully-owned subsidiary of Swedbank group. The name Hansabank was used for Baltic operations of Swedbank until 2009, when they were rebranded under the Swedbank name.

**Data for 2005 .

2009. In the second quarter of 2009, Swedbank encountered the highest share of impaired loans (as gross \% of total lending to public) in Latvia (17.94\%) and Lithuania (8.7\%), followed by Estonia (5.77\%). Loan losses differ by each Baltic country due to the different extent of the economic recession and different lending developments in each country.

Third, both banks joined the loan guarantee fund provided by the Swedish government in order to issue debt with a government guarantee and strengthen their financing. Both Swedbank and SEB also raised fresh equity to improve their Tier 1 capital ratios. Both banks are thus employing measures to prepare themselves to absorb further loan losses from the Baltics. The extent of such losses remains to be seen, but it is estimated that the worst scenario would be if any of the Baltic exchange rate pegs collapsed. The concrete data for Swedish banks reveal that almost 50\% of the Swedish banks' loan losses have been assessed as stemming from the banks' operations in the Baltic countries, and around 
one third from operations in Sweden and other Nordic countries.

Finally, it is helpful to outline the performance of Swedbank, SEB and their Baltic subsidiaries prior to 2007 (Table 1).

Bank assets of Baltic subsidiaries significantly increased, which was accompanied by an increase in assets to Tier 1 capital ratio. This reflects the large increase in other investment in the Baltics between 2006 and 2007 (Figure 3). All banks achieved high profitability, as shown by a very high ROE. However, excessively high ROE can also imply a higher leverage and low equity levels.

\section{Measures for Financial Stabilization in the Baltics}

Against the background of crisis, the major policy measures taken by Baltic countries since the end of 2008 have been as follows.

Each country increased bank deposit guarantees (Estonia and Latvia to 50,000 Euro and Lithuania to 100,000 Euro) in order to stabilize their domestic bank systems. All 3 countries also introduced wage regulations and staff reductions for the public sector to reduce spending and budget expenditures.

Latvia, as the country worst affected by the current financial crisis, employed further policy measures. First, mandatory reserve requirements for banks were lowered by $2 \%$. Second, marginal lending facility was set up in Latvia to enable banks with the ability to obtain overnight liquidity from the central bank. Third, in December 2008 the Bank of Latvia signed a swap agreement with the central banks of Sweden and Denmark, which entitles the bank to borrow up to 500 million Euro.

Similarly, Bank of Estonia in February 2009 signed a currency swap agreement with the Swedish central bank. This enables Estonia to borrow up to 1.1 billion USD in an emergency.

Only Estonia adopted an early Euro adoption target (2011), which appears attainable according to the IMF and SEB. In July 2009, the Latvian central bank changed its Euro adoption target from 2012 to 2014. 
Lithuania does not have an official Euro adoption target date. During the current economic recession, it became more difficult for the Baltic countries to fulfill the Maastricht criteria needed for Euro adoption, notably the fiscal criteria (due to lower growth and public revenues, fiscal deficits continue to exceed the required $3 \%$ of GDP).

\section{What kind of economic growth can be more sustainable?}

It is impossible to predict the length and depth of the ongoing economic recession in the Baltics. However, we can draw some implications from the Baltic economic development.

Baltic economies show that over-dependence on an easily accessible foreign capital supplies (not in the form of long-term FDI), makes small economies very vulnerable, increasing the risk of a sharp slowdown in economic growth. In the future, policy decisions in response to credit booms will be conducted within the new EU regulatory and supervisory framework (as recommended by the de Larosiere Report). This could reduce excessive risk-taking by banks and reduce the risk of a sharp economic growth slowdown (as observed in the Baltics between 2007 and 2008).

As a long-term strategy, international institutions such as the IMF or EBRD have frequently pointed out that the Baltic economies need to switch from non-tradable sector to the tradable sector and increase exports in order to achieve more sustainable economic growth. Since Baltic States have a limited manufacturing base and a small labor market exerting upward pressure on local wages, it would be desirable to attract more FDI into high value-added sectors, such as ICT or pharmaceuticals. Active efforts in this direction have recently been observed. 


\section{Conclusion}

This paper illustrated a divergence among the seven new EU member states prior to 2007: three Central European countries relied on FDI (a relevant share of which was channeled into manufacturing), while Hungary relied mostly on portfolio inflows and other investment was predominant in the Baltics. The most severe economic recession after 2007 was observed in the Baltics (and Hungary). We outlined how the credit booms in the Baltics were funded by large borrowing from foreign parent banks resulting in real estate market bubbles that proved unsustainable even before the 2008-09 financial crisis in the EU.

This paper also demonstrated that it is not always adequate to treat the Baltic States as one region by pointing out specific features of Lithuania and Latvia. We showed that foreign banks (unlike Latvian Parex bank) involved in the Baltics are able to cope with economic downturn in these countries.

In future research agendas, it will be important to monitor how the Baltic States continue in their domestic adjustments that are necessary to overcome the current economic recession without currency devaluation.

Credit booms and the subsequent recession in the Baltic States pose the question of why were the regulatory and supervisory authorities in the Baltics not able to curb excessive lending by foreign banks. The need for a new EU regulatory and supervisory framework has already been acknowledged by the European Commission. Future research will investigate in detail how the Baltic and Scandinavian authorities can enhance their cooperation in this direction. Other salient issues that need to be analyzed closely in future research include fiscal policy responses by the Baltic States and sharing of a fiscal burden in the case of bank crisis resolution.

This paper showed that FDI in manufacturing remained limited in Estonia and Latvia, when compared to the CEE countries. The problem of 
real economies in the Baltics therefore needs to be clarified. Future research should include a comparison with other countries of Eastern and South-Eastern Europe, such as Romania, Bulgaria (another country with a currency board arrangement), Croatia and Ukraine that have also experienced credit booms resembling those in the Baltics. Research on these topics will offer useful insights towards deeper understanding of the occurrence of credit booms and bubbles.

This paper was presented at the 30th EUSA - Japan conference held at Doshisha University, 14-15 November 2009. The author is thankful to Prof. Y. Hasumi (Rissho University) who was the chairperson of this conference section, to Prof. Y. Koyama (Niigata University), Dr. S. Sakamoto (Waseda University), Prof. A. Belke (University of Duisburg-Essen), Prof. H. Kubo (Kobe University) and Prof. M. Yoshii (Kobe University) for their valuable comments, which have been included into the final version of the paper to the greatest possible degree. The issues requiring further research have been added into the conclusion. The author is also very grateful to two anonymous referees for helpful comments.

1) When comparing the Baltics with 4 Central and Eastern European countries (CEE) that joined the EU in 2004, this paper excludes Slovenia (due to its specific geopolitical and socio-economic background).

2) Baltics started from below 40 of GDP per capita $(\mathrm{EU}-25=100)$, a level lower than in CEE, but after 6 years reached the levels of 55 and 65. (Eurostat).

3 ) In 2004-06 private consumption on average grew by $10-13 \%$ in the Baltics (compared to $2.8-5.8 \%$ in $\mathrm{CEE}$ ) and the contribution of domestic demand to GDP growth ranged between $10-16 \%$ in the Baltics (compared to 2.5-6\% in CEE). (European Commission (2007), Economic Forecasts Spring 2007).

4) Private sector credit-to-GDP ratio in 2006 was as high as $78 \%$ in Estonia and Latvia and $51 \%$ in Lithuania, while it was 55\% in Hungary and around $40 \%$ and less in CEE. (IMF, International Financial Statistics).

5 ) Compared to 2004, in 2005 credit grew by more than $60 \%$ in Lithuania and Latvia, by nearly $40 \%$ in Estonia, while credit growth in CEE was $26 \%$ or less. (IMF, International Financial Statistics).

6) In December 2007, the share of foreign currency loans for all sectors was $80 \%$ or higher in Estonia and Latvia and around 50\% in Lithuania. Lithuania resembles Hungary, 
『日本 $\mathrm{EU}$ 学会年報』第30号, 平成 22 年 4 月

which had the highest share of foreign currency loans in CEE. (European Commission, Convergence Report 2008).

7) IMF, International Financial Statistics and National Central Banks data.

8 ) Current account deficits of CEE in 2001-08 never exceeded $9 \%$ of GDP, while in all Baltic States they exceeded 10\% of GDP after 2005. (The same reference as number 6).

9) Hungary relied mostly on portfolio inflows. (The same reference as number 7).

10) All Baltic States had loan to deposit ratios higher than $140 \%$ in 2007, Hungary's loan to deposit ratio was $128 \%$, while in $3 \mathrm{CEE}$ countries the ratios ranged between $72 \%$ and $91 \%$. (ECB (2008), EU Banking Structures). Claims by the foreign banks in the Baltics and Hungary clearly differed from $3 \mathrm{CEE}$ countries: while foreign banks in the Baltics and Hungary had more international claims than local claims in local currency (i. e. banks' claims in these states consisted of cross-border claims and local claims in foreign currencies), foreign banks in $3 \mathrm{CEE}$ countries focused on local lending in local currencies. (BIS, Quarterly Review, various issues).

11) FDI distribution data described in this paragraph is based on E. Banincova (2008), "EU Enlargement and Foreign Direct Investment in Central and Eastern Europe and three Baltic states”, Kyusyu Keizaigakkai Nenpo, No.46, December 2008, pp. 31-37 (in Japanese) and E. Banincova (2008), "FDI Pattern in Central and Eastern Europe and in the three Baltic countries since 1990s - Analysis by Investing Country and Industry”, The Keizai Ronkyu, No. 131, Kyushu- Daigaku, Daigakuin- Keizaigakukai, July 2008, pp.67-81 (in Japanese). Difference of Lithuania from the other two Baltic States stems from its larger economic size and different industrial development in the former Soviet era, among other factors.

12) In 2007 owner occupation rate was $96 \%$ in Estonia, $97 \%$ in Lithuania and $87 \%$ in Latvia, compared to $65 \%$ of EU-15. The rate was high in Hungary (92\% in 2003) and Slovakia (81\% in 2007), while it was lower in Poland (75\% in 2004) and Czech Republic (58.7\% in 2007). (EMF (2007), Hypostat, p. 60).

13) Annual \% change in house prices was $42 \%$ in Estonia (in 2004 and 2005) and $48.6 \%$ in Riga in 2005, while it was $22 \%$ in Vilnius (in Q1 2007). (European Housing Review (EHS) 2007 by RICS and Knight Frank Residential Research database).

14) In March 2007 the number of average monthly wages necessary for buying 1 square meter of standard apartment in Riga equaled 4.1. (Bank of Latvia, Financial Stability Review 2008, p. 10).

15) In Estonia young adults could get mortgage loan guarantees from KredEx up to $24 \%$ of the value of collateral if they owned funds equivalent to $10 \%$ value of the property they aimed to buy. (Enoch Ch. and Otker-Robe Inci editors (2007), Rapid Credit Growth in Central and Eastern Europe: Endless Boom or Early Warning? IMF, Palgrave, p. 63).

16) By persuading Baltic citizens that purchase of real estate has good prospects, press 
Baltic Economies and Financial Crisis in the EU (Banincova)

and real estate agents encouraged speculative transactions. Foreign investors allegedly sought mainly Tallinn downtown real estates. (EHS 2007 by RICS and Eesti Pank (2005) Financial Stability Review, November 2005 p.38).

17) Eurostat, Economy and finance, Interest rates, Money market rates (ECB).

18) Since joining ERM II in June 2004, Estonia and Lithuania have continued their currency board arrangements as unilateral commitment, which enhanced discipline within ERM II. Latvia joined ERM II in May 2005 and continued to keep $\pm 1 \%$ fluctuation band as a unilateral commitment. In 2004, Estonia and Lithuania planned to adopt the Euro in 2007 and Latvia in 2008.

19) Bank of Lithuania (2006), Financial Stability Review, p. 15.

20) Calculated from the monthly average of the difference between domestic 3-month interbank rate and the 3-month EURIBOR. The same calculation and data source apply to Estonia's and Lithuania's interest differentials. (Eurostat, Economy and finance, Interest rates, Money market rates (ECB).

21) Raoul Lattemae (2007), "Estonia's Experience with Rapid Credit Growth” in Enoch Ch. and Otker-Robe Inci editors (2007), Rapid Credit Growth in Central and Eastern Europe: Endless Boom or Early Warning?? IMF, Palgrave, p. 176-177.

22) Household and corporate debt (as \% of GDP) increased considerably. In 2008 it was 109\% in Estonia, 84\% in Latvia and 59\% in Lithuania. (Database of Swedish central bank Riksbank).

23) Explanations of the end of housing bubble are based on Financial Stability Reports by National Central banks of Baltic States.

24) As part of future research agendas, the author will compile data showing the gap between the market property prices and the theoretical property prices in the Baltic States.

25) SEB Bank (2010), "Prospects of Lithuanian Economy in 2010-2011" presentation, mimeo, January.

26) In 2008 issued debt securities together with inter-bank borrowing represented $47 \%$ of Swedish banks' funding, while deposits accounted for 46\%. (Riksbank's database).

27) Residential property prices in Riga started to decline since Q2 2007 and the annual \% change of property prices in Riga reached $-20 \%$ in Q1 2008. In Estonia, decline started since Q3 2007 with the annual \% change of Tallinn property prices of -11\% in Q1 2008. In Lithuania, growth of residential prices slowed down since Q2 2007 and the annual \% change of Vilnius property prices was $0.5 \%$ in Q1 2008. (Knight Frank Residential Research and IMF (2008) Regional Economic Outlook: Europe-Dealing with Shocks, p. 14).

28) Riksbank's database.

29) World Bank (2009), EU10 Regular Economic report, February 2009, page 11. 
『日本 $\mathrm{EU}$ 学会年報』第30号, 平成 22 年 4 月

30) BSCEE Review 2007.

31) Non-resident deposits were mainly from Russia and ex-CIS countries. (According to the "Overview of JSC Parex Banka Takeover" by Latvia's Financial and Capital Market Commission, accessible at: http://www. fktk. lv/en/publications/other_publications/200905-15_overview_of_jsc_parex_ba/).

32) IMF (2009), IMF Country Report No. 09/3, p. 4.

33) For instance, wages and bonuses in the public sector are to be reduced by $25 \%$ in 2009, compared to 2008. (Ibid., p. 18).

34) In 2009, Latvia's central bank governor frequently stated that devaluation would not help the economy by boosting exports, and that demerits would largely outweigh any benefits (www. baltictimes. com).

35) In June 2009 Latvian treasury failed in its bid to sell state debt. When the Swedish central bank stated it would increase currency reserves in June 2009, concerns about the credibility of Latvian peg intensified. (Press releases by Riskbank and The Baltic Times on www. baltictimes. com).

36) Claims by Swedish banks as \% of total foreign claims in Estonia were 78\%, in Latvia $58 \%$ and in Lithuania 57\% (end-2005). (A. Gersl (2007), "Foreign Banks, Foreign Lending and Cross-border Contagion: Evidence from BIS data", Czech Journal of Economic and Finance 57, p. 9).

37) Riksbank, Financial Stability Report June 2009, p. 44.

38) A. Borg (2009), Swedish Perspective on the Crisis, presentation at Peterson Institute for International Economics.

39) The same reference as number 37, p. 81.

40) Interim Reports Jan-June 2009 and press releases by Swedbank and SEB.

41) Ibid. SEB strengthened its Tier 1 capital ratio to $11.4 \%$ (September 2009) and SEB to 13.1\% (Q2 2009). Besides, in Q2 2009, SEB decided on write-off of goodwill for the Baltics totaling 2,317 million SEK.

42) Riksbank, Financial Stability Report November 2009, p. 11.

43) The same reference as number 29, pp. 38-39 and press releases by National Central Banks.

44) IMF, Republic of Estonia- 2009 Article IV Consultation Concluding Statement, 26/10/ 2009 and SEB Economic Research (2009), Eastern European Outlook, October 2009, p. 7.

45) The Banker, May 2009, pp. 132-133. 